\title{
Demokratisasi dalam Rangka Pembangunan Hukum Responsif
}

\author{
Sanusi ${ }^{1}$, Soesi Idayanti ${ }^{2}$, Tiyas Vika Widyastuti ${ }^{3}$ \\ Universitas Pancasakti Tegal \\ Masuk: 26 Maret 2020; Diterima: 30 November 2020; Terbit: 30 November 2020. \\ DOI: $10.24905 /$ diktum.v8i2.84
}

\begin{abstract}
This research is conceptual research that intends to examine the idea of democracy in progressive legal development. As a means of state policy, the development of laws carries a variety of implications. During that time the law was only understood as a rigid rule and put too much emphasis on aspects of the legal system regardless of the relationship between the law and the issues that had to be addressed, such as social issues. The law is synonymous with the order as a mirror of the regulation of the ruler, on the other hand, there is also an understanding of the law that emphasizes more on the legitimacy aspect of the rule itself. Responsive law is results-oriented, i.e. on goals that will be achieved outside the law. A hallmark of responsive law is the search for implied values contained in rules and policies. In this responsive legal model, they express disapproval of what they consider to be standardized and inflexible interpretations. Legal products that are responsive to the manufacturing process is democratic, namely participation, which invites the participation of as many elements of society as possible, both in terms of individuals, and community groups, and must also aspire to come from the wishes or desires of the community. This means that the product of the law is not the authority of the ruler to simply legitimize his power.
\end{abstract}

Keywords: Democratization, Development, Legal Responsibility.

\begin{abstract}
Abstrak
Sebagai sarana kebijakan negara, perkembangan hukum membawa berbagai implikasi. Selama itu hukum hanya dipahami sebagai aturan-aturan yang bersifat kaku dan terlalu menekankan pada aspek the legal system tanpa melihat kaitan antara hukum tersebut dengan persoalan-persoalan yang harus ditangani, seperti masalah-masalah sosial. Hukum identik dengan ketertiban sebagai cermin pengaturan dari penguasa, disisi lain ada juga pemahaman mengenai hukum yang lebih menekankan pada aspek legitimasi dari peraturan-peraturan itu sendiri. Hukum responsif berorientasi pada hasil, yaitu pada tujuan-tujuan yang akan dicapai di luar hukum. Ciri khas hukum responsif adalah mencari nilai-nilai tersirat yang terdapat dalam peraturan dan kebijakan. Dalam model hukum responsif ini, mereka menyatakan ketidaksetujuan terhadap doktrin yang dianggap mereka sebagai interpretasi yang baku dan tidak fleksibel. Produk hukum yang berkarakter responsif proses pembuatannya bersifat demokratis yaitu adanya partisipasif, yakni mengundang sebanyak-banyaknya partisipasi semua elemen masyarakat, baik dari segi individu, ataupun kelompok masyarakat dan juga harus bersifat aspiratif yang bersumber dari keinginan atau kehendak dari masyarakat. Artinya produk hukum tersebut bukan kehendak dari penguasa untuk sekedar melegitimasikan kekuasaannya.
\end{abstract}

Kata Kunci: Demokratisasi, Pembangunan, Hukum Responsif.

\footnotetext{
${ }^{1}$ Coresponding author:

Sanusi6263@gmail.com
} 


\section{A. Pendahuluan}

Dewasa ini barangkali hukum menjadi satu-satunya ideologi buatan manusia yang diterima dalam kehidupan masyarakat modern, baik dalam lingkup negara, antar negara maupun masyarakat internasional. Sebagai ideologi. hukum memberikan kekuatan dan sekaligus harapan , khususnya yang berupa keadilan bagi masyarakat. Peranan hukum dalam kehidupan masyarakat adalah sebagai norma yang mengatur ataupun memberikan larangan maupun sebagai kontrol sosial .

Sebagai sarana kebijakan negara, perkembangan hukum membawa berbagai implikasi. Banyak keluhan pada produk hukum pada era orde baru yang berkarakter ortodok atau tidak responsif terhadap perkembangan dan tuntutan masyarakat. Dalam karakter pembangunan hukum ortodok, dalam pembuatannya relatif tertutup terhadap tuntutan-tuntutan kelompok masyarakat atau individu-individu dalam masyarakat sehingga muatannya mencerminkan visi sosial elit politik atau lebih mencerminkan keinginan pemerintah atau lebih merupakan alat bagi pelaksanaan keinginan para pemegang kekuasaan negara (Mahfud, 2001).

Hukum juga sebagai salah satu alat rekayasa sosial. Diterimanya pandangan bahwa hukum sebagai rekayasa sosial memberikan pemahaman bahwa hukum adalah buatan manusia sebagai keputusan politik. Sebagai keputusan politik hukum diwarnai oleh tujuan-tujuan, kepentingankepentingan, dan selektifitas serta dipengaruhi oleh konteks kondisi-kondisi sosial, ekonomi,politik,budaya,hukum dan hamkan serta struktur-struktur lain yang ada. Akan tetapi pengaruh pengetahuan dan teknologi serta globalisasi telah mempercepat perkembangan dan perubahan masyarakat diberbagai aspek kehidupan. bukan saja bidang ekonomi, akan tetapi juga dibidang sosial dan nilai-nilai seperti Hak Asasi Manusia (HAM) dan demokrasi. Terdapat tuntutan yang terus menerus dari masyarakat terhadap perlindungan dan pelaksanaan 
hak-hak asasinya dan perluasan terhadap hak-hak demokrasinya dalam rangka pembangunan hukum yang responsif yakni produk hukum yang lahir dari strategi pembangunan hukum yang memberikan peranan besar dan mengundang partisipasi penuh kelompok-kelompok sosial atau individuindividu dalam masyarakat dalam mencerminkan rasa keadilan dan memenuhi harapan masyarakat.

Melihat latar belakang diatas, maka permasalahan hukum yang perlu diteliti adalah bagaimana strategi dalam mewujudkan karakter produk hukum responsif dan bagaimana demokratisasi dalam mewujudkan pembangunan hukum yang responsive.

\section{B. Pembahasan}

\section{Strategi Dalam Mewujudkan Karakter Produk Hukum Responsif}

Hukum adalah produk politik, artinya bahwa hukum itu dipandang dari rumusan pasal-pasalnya adalah merupakan kristalisasi dari kehendak-kehendak politik yang saling bersaingan sehingga wataknya akan sangat ditentukan oleh konfigurasi politiknya. Karakter yang menonjol dari situasi seperti ini adalah lebih diutamakan tujuan, isi dan substansi daripada prosedur atau cara-cara untuk mencapai tujuan-tujuan tersebut (Satjipto Rahadjo, 1985). Pada masa Orde Baru sebagai suatu sistem politik yang menempatkan pemerintah pada posisi dominan untuk menentukan kebijakan negara dan rakyat harus menerimanya sebagai produk yang tidak dapat ditawar. Produk hukumnya karakternya mencerminkan visi politik pemegang kekuasaan dominan dan pembuatannya tidak mengundang partisipasi dan aspirasi masyarakat secara benar-benar sehingga adanya prosedur penyerapan aspirasi lebih bersifat formalitas belaka. (Yunanto, 2010)

Ruang hukum menjadi sempit, terjepit oleh berbagai kepentingan. Akibatnya hukum yang benar berada di awang-awang. Politik hukum 
pada masa itu tujuannya adalah membentuk hukum yang menguatkan kekuasaan seperti pada zaman orde baru dimana hak politik dibungkam dengan pemerintahan yang otoriter menangkap lawan politik yang tidak sejalan dengan rezim pemerintahan saat itu, sehingga hukum yang dihasilkan itu akan menjauhkan tata hukum dari realitas masyarakat. Tujuannya adalah mempertahankan kekuasaan dengan dijadikannya hukum sebagai alat untuk meredam perlawanan dari kekuasaan politik yang tidak sejalan dengan kebijakan orba, dengan cara memperluas kekuasaan melalui Ketetapan Majelis Permusyawaraatan Rakyat (MPR).

Pada rezim ini menjadikan pemerintah menjadi autokrasi, yang tidak lagi mengenal pertanggungjawaban dalam arti sebenarnya, karena semua lembaga pengawasan mulai dari Dewan perwakilan Rakyat (DPR), Badan pemeriksa Keuangan (BPK), Kejaksaan, sudah berada dibawah pengaruh rezim kekuasaan tersebut. Hal ini menunjukan dominasi orba sangat mutlak maka konfigurasi politik di parlemen menjadi non demokratis. Bentuk nyata dari autokrasi rezim ini adalah terjadinya praktik korupsi, kolusi, dan nepotisme dari para pejabat negara dan masing-masing lembaga kekuasaan dikendalikan oleh rezim penguasa. (Handoyo, 2018)

Orde baru dalam kebijakan pembangunan ekonomi menerapkan ekonomi liberal atau kapitalis, dan untuk mendapatkan dukungan dari rakyat, rezim ini memang melakukan pembangunan nasional secara sentralistik salah satunya adalah dengan banyaknya peraturan perundangundangan yang dibuat oleh penguasa. Akibatnya kesenjangan dalam masyarakat semakin tajam. Hal ini menimbulkan munculnya oposisi dalam masyarakat yang dipelopori oleh golongan menegah mahasiswa dan Lembaga Swadaya Masyarakat (LSM). (Parlindungan, 2018)

Gerakan Mahasiswa Indonesia 1998 adalah puncak gerakan mahasiswa dan gerakan rakyat pro-demokrasi pada akhir dasawarsa 1990- 
an. Setelah era orde baru digantikan dengan era reformasi melalui reformasi mahasiswa tersebut, didalamnya dilakukan perombakan besarbesaran dengan tujuan membentuk negara yang demokratis. Awal reformasi konfigurasi politik telah berhasil melahirkan produk hukum yang responsif. Harus dipahami bahwa upaya mengubah hukum menjadi responsif harus didahului dengan perubahan konfigurasi politik agar menjadi demokratis, sebab tidak mungkin hukum responsif lahir dari politik yang tidak demokratis. Tidak dapat dipungkiri peristiwa demonstrasi besar oleh mahasiswa yang dilakukan pada tahun 1998 mampu menggulingkan tampuk kekuasaan yang otoriter dimana angin segar akan reformasi dan demokrasi dijunjung tinggi.

Konfigurasi partisipasi masyarakat secara penuh untuk aktif menentukan kebijakan umum partisipasi dalam proses pembentukan undang-undang dengan melahirkan empat kaidah nilai-nilai dasar dalam pembangunan hukum.Pertama : hukum nasional harus dapat menjaga integritas (keutuhan kesatuan) baik ideology maupun teritori sesuai dengan tujuan melindungi segenap bangsa dan seluruh tumpah darah Indonesia. Sehingga harus dicegah munculnya produk hukum yang berpotensi memecah belah keutuhan bangsa dan negara Indonesia. Kedua, hukum nasional harus mampu menciptakan keadilan sosial dalam arti harus mengundang partisipasi dan menyerap aspirasi masyarakat luas melalui mekanisme yang fair,transparan dan akutabel. Ketiga. Hukum nasional harus mampu memperpenddek jurang antara yang kuat dan yang lemah serta memberi proteksi khusus terhadap golongan yang lemah dalam berhadapan dengan golongan yang kuat baik daari luar maupun dari dalam negeri sendiri (Mahfud, Capaian Dan Proyeksi Kondisi Hukum Indonesia, 2009). Keempat, hukum harus menjamin toleransi beragama yang berkeadaban antara pemeluknya. (Azhary, 1992) 


\section{Demokratisasi dalam Mewujudkan Pembangunan Hukum Responsif}

Dalam menuju ke demokrasi yang kita dambakan merupakan proses yang tidaklah mudah. Konsep hukum responsif diidentifikasi berdasarkan proses pembuatan hukum, pemberian fungsi hukum, dan kewenangan menafsirkan hukum. Untuk selanjutnya pengertian secara konseptual dirumuskan sebagai berikut :

a. Konfigurasi politik demokratis adalah konfigurasi yang membuka ruang bagi partisipasi masyarakat untuk terlibat secara maksimal dalam menentukan kebijakan negara. Konfigurasi politik demikian menempatkan pemerintah lebih berperan sebagai organisasi yang harus melaksanakan kehendak masyarakatnya, yang dirumuskan secara demokratis. Oleh karena itu badan perwakilan rakyat dan partai politik berfungsi secara proporsional dan lebih menentukan dalam pembuatan kebijakan negara. Pers terlibat dalam menjalankan fungsinya dengan bebas tanpa ancaman pembreidelan atau tindakan kriminalisasi lainnya.

b. Produk hukum responsif adalah karakter produk hukum yang mencerminkan pemenuhan atas aspirasi masyarakat, baik individu maupun berbagai kelompok sosial, sehingga secara relatif lebih mampu mencerminkan rasa keadilan di dalam masyarakat. Proses normatifikasinya mengundang secara terbuka partisipasi dan aspirasi masyarakat. Lembaga peradilan dan peraturan hukum berfungsi sebagai instrumen pelaksana bagi kehendak masyarakat, sedangkan rumusannya biasanya cukup diperinci sehingga tidak terlalu terbuka untuk ditafsirkan dan diinterpretasikan berdasarkan kehendak dan visi penguasa/pemerintah secara sewenang-wenang. (Marpaung, 2003) 
Demokrasi yang menjadi kata kunci dalam gerakan reformasi di bulan mei 1998 ternyata bahwa proses serta produk hukumnya masih jauh dari tujuan ideal yang hendak kita capai. Tujuan hukum berdasarkan cita hukum Pancasila yaitu mewujudkan pengayoman hingga menciptakan keadilan masyarakat dalam memperoleh kesempatan yang luas dan sama untuk mengembangkan seluruh potensi kemanusiaannya secara utuh belum sepenuhnya dirasakan oleh masyarakat. Termasuk juga tujuan memelihara dan mengambangkan "budi pekerti kemanusian serta cita-cita moral rakyat yang luhur berdasarkan Ketuhanan Yang Maha Esa sesuai Penjelasan Undang-Undang Dasar 1945.

Demokrasi dikonsepkan sebagai sistem politik yang membuka peluang bagi berperannya potensi rakyat secara maksimal untuk turut aktif dalam penentuan kebijakan negara sehingga pemerintah dituntut untuk tunduk pada kehendak-kehendak rakyatnya yang dikontensikan secara fair. Tidak mungkin kita dapat melakukan reformasi hukum kearah yang lebih baik jika sistem politik yang ada sekarang ini tidak direformasi lebih dahulu. Dalam konteks yang demikian itulah kemudian diperlukan strategi dalam upaya membangun hukum yang dikehendaki oleh masyarakat dan hukum yang berpihak pada masyarakat. (Pratama, 2020)

Produk hukum yang berkarakter responsif mensyaratkan sesuatu yang lebih daripada sekedar keadilan procedural tetapi mampu mengenali keinginan masyarakat. Produk hukum yang berkarakter responsif adalah produk hukum yang karakternya mencerminkan pemenuhan atas tuntutan-tuntutan individu-individu maupun berbagai kelompok sosial di dalam masyarakat sehingga lebih mampu pula mencerminkan rasa keadilan dalam masyarakat. Ada dua indikatornya yaitu (Mahfud, Konfigurasi Politik dan Karakter Produk Hukum, Otoriter dan Konservatif, 1995): 
a. Pada konfigurasi politik demokratis,parpol dan lembaga perwakilan rakyatnya dominan dalam dalam menentukan haluan negara, ada jaminan kebebasan pers untuk menggali, mengolah dan menyampaikan informasi kepada masyarakat, dana lembaga eksekutifnya cnderung menempatkan diri sebagai lembaga yang melaksanakan kehendak-kehendak rakyat dikristalkan melalui konststasi yang fair.

b. Pada produk hukum yang berkarakter responsif pada umumnya dibuat melalui proses partisipatif dengan mengundang partisipasi masyarakat dan lembaga peradilan untuk turut menentukannya, diberi fungsi aspiratif untuk menampung sebanyak mungkin aspirasi masyrakat sehingga isinya mencerminkan kehendak dan aspirasi masyaraakat, dan muatan materinya limitatif dalam arti cukup rinci dan jelas sehingga tidaak dapat ditafsirkan secara sepihak oleh lembaga eksekutif (pemerintah)

Karena karakter produk hukum sangat ditentukan oleh konfigurasi politik yang melahirkannya, maka setiap keinginan untuk membangun hukum dengan karakter tertentu haruslah dimulai dari penataan konfigurasi politiknya. Dengan kata lain jika pembangunan hukum akan diarahkan pada penciptaan hukum yang berwatak responsif maka independent variabelnya yaitu konfigurasi politik harus digeser kearah yang lebih demokratis. Sebab hukum yang responsif hanya dapat dilahirkan oleh konfigurasi politik yang demokratis.

Upaya demokratisasi dalam rangka pembangunan hukum yang responsif ini mencakup keharusan pemberian kesempatan yang seluasluasnya untuk partisipasi bagi mereka yang menjadi sasaran kebijakan politik baik dalam mengambil keputusan-keputusan khusus maupun didalam merumuskan berbagai definisi situasi yang merupakan dasar 
dalam pengambilan keputusan tersebut. Semua hasil itu berakibat pada semakin banyaknya anggota masyarakat yang mempunyai kapasitas politik yang semakin baik yang pada gilirannya akan membawa pada lahirnya tuntutan terhadap peningkatan kualitas demokrasi dan pembangunan hukum yang responsif.

Upaya demokratisasi dalam rangka pembangunan hukum yang responsif ini mencakup keharusan pemberian kesempatan yang seluasluasnya untuk berpartisipasi bagi mereka yang menjadi sasaran kebijakan politik baik di dalam mengambil keputusan-keputusan khusus maupun di dalam merumuskan berbagai definisi situasi yang merupakan dasar dalam pengambilan keputusan tersebut.

Tujuan utamanya adalah adanya supremasi hukum adalah menjadikan hukum sebagai pimpinan dalam menjalankan kehidupan berbangsa dan bernegara, yang mana apabila tujuan tersebut tercapai dapat menghasilkan beberapa hal seperti meningkatkan integritas sumber daya manusia, memberikan keadilan sosial, menjaga nilai moral bangsa, menciptakan masyarakat yang demokratis, serta memberi jaminan perlindungan hak individu dalam bernegara dan bermasyarakat.

\section{Simpulan}

Pembangunan hukum di Indonesia menghendaki agar hukum dapat dijadikan sandaran dan kerangka acuan. Untuk itu kita perlu menciptakan hukum yang berkarakter responsip. Upaya membangun hukum responsif perlu didahului dengan demokratisasi dalam kehidupan politik sebab setiap karakter produk hukum sangat berpengaruh oleh konfigurasi politik yang melahirkannya. Dengan kata lain konfigurasi politik akan sangat menentukan karakter produk hukum. Konfigurasi politik yang demokratis akan memberi jalan lahirnya hukum yang responsif yaitu produk hukum yang memberikan 
wadah kepada masyarakat untuk turut memberikan aspirasinya dalam proses pembentukan produk hukum.

\section{Daftar Pustaka}

Azhary, M. T. (1992). Negara Hukum . Jakarta: Bulan Bintang.

Handoyo, B. (2018). Konfigurasi Politik Hukum Pertanahan Indonesia dalam Perspektif Teori Hukum Responsif. AT-TASYRI': JURNAL ILMIAH PRODI MUAMALAH, 21-38.

Mahfud, M. (1995, Juli 7). Konfigurasi Politik dan Karakter Produk Hukum, Otoriter dan Konservatif. Artikele Majalah Prisma, pp. 17-33.

Mahfud, M. (2001). Politik Hukum di Indonesia. Jakarta: Pt Pustaka LP3ES.

Mahfud, M. (2009). Capaian Dan Proyeksi Kondisi Hukum Indonesia. Jurnal Hukum, $16(3), 292-293$.

Marpaung, L. A. (2003). Pengaruh Konfigurasi Politik Hukum Terhadap karakter Produk Hukum,(suatu telaah dalam perkembangan hukum pemerintahan daerah di Indonesia. Jurnal Univ Bandar lampung, 54-64.

Parlindungan, G. T. (2018). Prinsip-prinsip Negara Hukum dan Demokrasi Dalam Pembentukan Peraturan Daerah. Jurnal Hukum Respublica, 16(2), 384-400. doi:https://doi.org/10.31849/respublica.v16i2.1447

Pratama, E. A. (2020). Business Ethics And Legal Liability In The Management Of State-Owned Enterprises. Journal of Critical Reviews, 7(15), 1401-407. Retrieved from http://www.jcreview.com/?mno=22413

Satjipto Rahadjo. (1985). Hukum Dalam Perspektif Sejarah dan Perubahan SosPembangunan Hukum dalam Perspektif Hukum Nasional. Jakarta: LBH.Yogyakarta dan Rajawali.

Yunanto. (2010). Menuju Strategi Pembangunan Hukum yang Responsif. e-journal Undip, 164-171. 